Western North American Naturalist 68(2), (C) 2008, pp. 249-250

\title{
FIRST RECORD OF DIAMONDBACK MOTH (LEPIDOPTERA: PLUTELLIDAE) FROM INTERIOR ALASKA
}

\author{
Aaron M. Hagerty ${ }^{1,2}$, Alberto Pantoja ${ }^{1}$, and Susan Emmert ${ }^{1}$
}

\begin{abstract}
The diamondback moth (Plutella xylostella [L.]), is one of the most economically important pests of cruciferous plants throughout the world, causing economically significant damage in broccoli, cabbage, canola, collards, and mustard. In Canada, P. xylostella is an important economic pest of canola (Brassica napus L. and Brassica rapa L.). In North America, the diamondback moth has been collected as far north as Edmonton, Alberta, Canada. Despite its wide distribution and presence at economically damaging levels in Canada, there have been no published reports of $P$. xylostella from Alaska. This note documents the 1st collection of this pest species in interior Alaska. With continued moderation of the climate due to global climate change, this species has the potential to become an increasingly important agricultural pest in the state.
\end{abstract}

Key words: Alaska, diamondback moth, Brassica production.

The diamondback moth (Plutella xylostella [L.]; Lepidoptera: Plutellidae) is one of the most economically important pests of cruciferous plants throughout the world, causing economic damage in cultivated Brassica spp. such as broccoli, cabbage, canola, collards, and mustard (Talekar and Shelton 1993). The cosmopolitan distribution of $P$. xylostella is due primarily to the extensive cultivation of its host plant, Brassica spp., and its tendency to migrate long distances (Chu 1986).

In North America, the diamondback moth has been collected as far north as Edmonton, Alberta, Canada (UASM 2007). However, $P$. xylostella has been reported as an economic pest of canola (Brassica napus L. and Brassica rapa L.) in western Canada (Dosdall et al. 2001). Despite its wide distribution and presence at economically damaging levels in Canada (Dosdall et al. 2001), there have been no published reports of $P$. xylostella from Alaska (CIE 1967). In addition, Lafontaine and Wood (1997) do not list it among the lepidopteran fauna of the Yukon. Rasy and Lung (2003) mention "diamondback moth" as a landscape tree pest on cotoneaster (Cotoneaster sp.: Rosaceae) and honeysuckle (Lonicera sp.: Caprifoliaceae) in the Anchorage area. Because P. xylostella is oligophagous on Brassicaceae (Sarfraz et al. 2006), Rosy and Lung's comments probably stem from a misidentification of the honeysuckle moth, Ypsolopha dentella Denis and Schiffermüller (Yponomeutidae), which superficially resembles the diamondback moth.

Diamondback moth larvae and subsequent crop damage were noted from small mixed plantings of Brassica spp. at 3 locations in interior Alaska (Fairbanks, Ester, and Nenana). Population density was assessed by visually examining plants in situ and recording the number of larvae present per plant. Due to small-scale plantings, sample sizes were limited. Random samples of 15-25 plants were examined periodically during June and July 2005. In Fairbanks, larval infestations were recorded from broccoli, cauliflower, cabbage, and brussels sprouts in mixed plantings at a density of 30.0 larvae $\left(s_{\bar{x}}=5.8\right)$ per 100 plants. Three larvae collected from the Fairbanks location were fixed in a hot water bath, preserved in ethanol, and compared to the larval descriptions of Moriuti (1986). An additional 10 larvae from the Fairbanks location and 3 larvae from the Nenana location were reared to adults on commercially prepared artificial cabbage looper diet (Southland Products Inc., Lake Village, AR). The resulting adults were spread, pinned, and held as voucher specimens to be deposited in the insect collection at the Museum of the North, University of Alaska, Fairbanks. Of those, 2 specimens $(1 \hat{0}, 1$ 우 $)$ were shipped to a collaborator, Dr. Richard Pluke (Fintrac Inc., U.S. Virgin Islands), for identification.

The origin of the Alaskan infestation remains in question. Some controversy exists over the

${ }^{1}$ USDA ARS, Subarctic Agricultural Research Unit, Room 360 O’Neill Building, Fairbanks, AK 99775.

2E-mail: ffamh1@uaf.edu 
ability of $P$. xylostella to overwinter in temperate areas (Talekar and Shelton 1993). Dosdall et al. (2001) reported no evidence of the ability of the diamondback moth to overwinter in western Canada and speculated that infestations resulted from strong winds carrying adults northward from the southern United States and Mexico. This speculation is supported by researchers in Europe who have documented long-range migrations of up to $3000 \mathrm{~km}$ (Chu 1986). Another possible source of the infestation is contaminated Brassica spp. seedlings imported from the contiguous United States. Talekar and Shelton (1993) reported that the diamondback moth is often introduced into temperate areas, where it does not have the ability to overwinter, via contaminated host-plant seedlings. In New York, the level of diamondback moth infestation of cabbage transplants from Florida has been reported to be as high as 19.7 insects per 100 transplants (Shelton et al. 1996). Host plants examined in Alaska during 2005 were all produced locally from seed; therefore, the source of diamondback moth infestations in interior Alaska remains unclear at this time. However, the diamondback moth is most likely an annual migrant to the state from the contiguous United States or Canada. Such long-range migrations of the diamondback moth have been reported in England and other northern European countries (Tallekar and Shelton 1993).

Because of the importance of cabbage and other cruciferous crops to Alaskan agriculture and because of the potential for economic damage, further research is needed to determine diamondback moth seasonality, population density, and mode of entry into the state. In addition, Dosdall et al. (2001) speculated that continued global climate change could produce conditions that are more favorable to P. xylostella outbreaks (i.e., warm and dry conditions) in western Canada. Since 1973, the winter temperatures in Alaska have increased by $2-3^{\circ} \mathrm{C}$ (Whitfield 2003). It is logical to assume that these climatic changes would prove advantageous for diamondback moth establishment in Alaska and that more frequent and damaging infestations of these pests may occur in the future.

We thank Tom Zimmer and Susan Willsrud at Calypso Farm and Ecological Center, Pat Holloway at UAF Georgeson Botanical Garden, and Sven Ebbesson at Ebbesson Farms for access to field sites. Technical assistance was provided by Bethany Sweet, Richard Ranft, and Bob Torgerson. We also thank Dr. Richard Pluke for identification confirmations.

\section{Literature Cited}

[CIE] Commonwealth Institute of Entomology. 1967. Distribution maps of plant pests, no. 32. CAB International, Wallingford, U.K.

Chu, Y. 1986. Migration of diamondback moth. Pages 77-81 in N.S. Talekar and T.D. Griggs, editors, Diamondback moth management: proceedings of the first international workshop, March 1986, Tainan, Taiwan. Asian Vegetable Research and Development Center.

Dosdall, L.M., P.G. Mason, O. Olfert, K. Kaminski, AND B.A. KEDDIE. 2001. The origins of infestations of diamondback moth, Plutella xylostella (L.), in canola in western Canada. In: N. Endersby, editor, Proceedings of the fourth international workshop: the management of diamondback moth and other crucifer pests, November 2001, Melbourne, Australia. Available from: http://www.regional.org.au/ au/esa/2001/.

Lafontaine, J.D., AND D.M. WoOD. 1997. Butterflies and moths (Lepidoptera) of the Yukon. Pages 723-785 in H.V. Danks and J.A. Downes, editors, Insects of the Yukon. Biological Survey of Canada (Terrestrial Arthropods), Ottawa, Ontario. 1034 pp.

Moriuti, S. 1986. Taxonomic notes on the diamondback moth. Pages 83-88 in N.S. Talekar and T.D. Griggs, editor, Diamondback moth management: proceedings of the first international workshop, March 1986, Tainan, Taiwan. Asian Vegetable Research and Development Center.

RASY, M., AND D. Lung. 2003. IPM technician activities, Anchorage district. Pages 12-13 in Alaska Statewide Integrated Pest Management Program: 2002 annual report. University of Alaska Cooperative Extension Service. $34 \mathrm{pp}$.

Sarfraz, M., L.M. Dosdall, and B.A. Keddie. 2006. Diamondback moth-host plant interactions: implications for pest management. Crop Protection 25: 625-639.

Shelton, A.M., M.K. Kroening, S.D. Eigenbrode, C. Petzold, M.P. Hoffman, J.A. Wyamari, W.T. Wilsey, R.J. Cooley, and L.H. Pedersen. 1996. Diamondback moth (Lepidoper: Plutellidae) contamination of cabbage transplants and the potential for insecticide resistance problems. Journal of Entomological Science 31:347-354.

Talekar, N.S., and A.M. Shelton. 1993. Biology, ecology, and management of the diamondback moth. Annual Review of Entomology 38:275-301.

UASM. 2007. E.H. Strickland Entomological Museum, University of Alberta, Edmonton, Alberta, Canada. Available from http://www.entomology.ualberta.ca/ searching_specimen_results.php?fmsn=plutella + xylostella \&vw $=2 \& s \bar{b}=1 \& c=1$

WhitfiELD, J. 2003. Alaska's climate: too hot to handle. Nature 425:338-339.

Received 28 March 2007 Accepted 29 October 2007 